MEJUAJUA: Jurnal Pengabdian pada Masyarakat
https://www.jurnal.yaspenosumatera.org/index.php/mejuajua
Volume 1 | Nomor 2 I Desember |2021|Hal. 9-15
e-ISSN: 2807-2634

\title{
Pelatihan Produksi Minuman Jahe Instan Ibu PKK Kampung Daling Tajuk Dilem-Bebesen-Aceh Tengah-Nanggroe Aceh Darussalam
}

\author{
Samran $^{1)}$, Alam Suhada ${ }^{2)}$, Elvy Oktima ${ }^{3)}$, Suprianto $^{1)}$, Sumardi $^{4)}$, Cut Fatimah $^{1)}$, Debi Meilani' ${ }^{1)}$, Fesri \\ Damai Riang Laia ${ }^{1)}$, Dian Zulkarnain Lubis ${ }^{1)}$
}

\begin{abstract}
${ }^{1}$ Program Studi Farmasi, Sekolah Tinggi Ilmu Kesehatan Indah, Medan, Indonesia; ${ }^{2}$ Kadis KBP3A
Kabupaten Aceh Tengah; ${ }^{3}$ Program Studi Farmasi, Sekolah Menengah Kejuruan Al Razi Sinar

Harapan, Medan, Indonesia; ${ }^{4}$ Fakultas Farmasi, Universitas Tjut Nyak Dhien, Medan, Indonesia
\end{abstract}

Keywords :

Minuman, jahe, instan

Corespondensi Author

Emai:ekahasbi@gmail.com

History Artikel

Received: 23-11-2021

Reviewed: 04-12-2021

Revised: 05-12-2021

Accepted: 05-12-2021

Published: 20-12-2021

DOI:

10.52622/mejuajuajabdimas.v1i1.15

\begin{abstract}
Abstrak.
Kampung Daling Tajuk Dilem ada di wilayah Bebesen, Aceh Tengah, Nanggroe Aceh Darussalam (NAD) sebagai objek Pengabdian oleh Tim PKM Program Studi S1 Farmasi STIKes Indah Medan dan Progran Studi Farmasi Sekolah Kejuruan Menengah (SMK) Al Razi Sinar Harapan Medan. Ibu anggota PKK Kampung Daling Tajuk Dilem bersama suami sebagai petani, terutama petani kopi. Kopi Arabika merupakan produk Primadona Aceh Tengah, dan Jahe dapat dijadikan pendamping dalam sajian Kopi Arabika yang sudah biasa dijadikan sebagai produk andalan Aceh Tengah dalam menarik wisatawan Domestik maupun Internasional dengan wisata alam Danau Lut Tawar. Minuman Jahe Instan (MJI) adalah sediaan olahan jahe menjadi serbuk siap saji dengan campuran air panas. Pelatihan dilakukan Tim PKM untuk melatih ibu anggota PKK Kampung Daling Tajuk Dilem memproduksi olahan jahe menjadi sediaan instan. Ibu-ibu peserta Tim PKK Kampung Daling Tajuk Dilem mengikuti dengan cukup antusias dan produk MJI Instan sesuai yang diharapkan.
\end{abstract}

This work is licensed under a Creative Commons Attribution 4.0 International

\section{PENDAHULUAN}

Satu dari 23 Kabupaten di NAD, Indonesia dengan ibu kota Takengon adalah Aceh Tengah, udara kota yang sejuk di punggung Bukit Barisan yang terbentang luas sepulau Sumatera, disebut Dataran Tinggi Gayo (1). Demikian juga Kab. Gayo Lues dan Bener Meriah dengan Blang Kejeren dan Simpang Tiga Redelong sebagai ibu kotanya. Pemandangan yang indah dan menawan mewarnai perjalanan dari Takengon ke Blang Kejeren sampai Simpang Tiga Redelong (2,3).

Suku terbesar penduduk Kabupaten Aceh Tengah adalah suku Gayo, lainnya adalah suku Aceh, Minang, Batak, Jawa, dan Tionghoa. dengan 99 \% sebagai muslim $(1,4)$. Kerbau ternak utama yang dipelihara masyarakat Gayo, sehingga jika berada di Aceh melihat banyak kerbau berati berada di Gayo. Profesi masyarakatnya sebagian besar sebagai petani. Kopi Arabika Aceh Tengah nomor wahid di dunia, luasnya $48.300 \mathrm{Ha}$, rerata produksi sebanyak $720 \mathrm{~kg} / \mathrm{Ha}(5,6)$. Komoditas penting lainnya: tebu seluas $8.000 \mathrm{Ha}$, coklat $2.322 \mathrm{Ha}$, dan selebihnya sayuran serta palawija . 
Danau Lut Tawar adalah danau yang dikelilingi Kec. Bebesen Kab. Aceh Tengah, daerah berpenduduk terbanyak dan padat (7). Bebesen berbatas langsung dengan Takengon Timur dan Takengon Barat merupakan wilayah Kec. Lut Tawar. Danau Lut Tawar salah satu tempat wisata Dataran Tinggi Gayo. Luas danau Lut Tawar $\pm 5.472 \mathrm{Ha}(17$ x $3.219 \mathrm{~km})$, danau yang mendatangakan banyak manfaat sebagai sumber kehidupan Suku Gayo (2). Danau Lut Tawar sering dikunjungi oleh wisatawan domestik maupun internasional $(4,8)$. Pemandangan yang indah dan menawan disuguhkan Danau Lut Tawar, karena ada di sekitar dua buah bukit hijau (3). Kekayaan flora dan fauna Aceh tersimpan di danau Lut Tawar, Depik, ikan yang hidup di danau tersebut (9-11).

Jahe selama ini di Tanah Gayo digunakan sebagai obat. Beras, jahe, kunyit, merica, awasacih, bungle, lebe, jeruk purut dan jiremanis diolah menjadai parem (11). Masa peracikan dan bentuk sediaan yang menedakan matah dengan parem. Peracikan matah saat bersalin, sedangkan bedak parem saat kehamilan (12).

Pelatihan dan bimbingan produsi MJI dapat menjadi pendamping produk kopi yang menjadi Primadona dan daya tarik wisata domestik maupun internasional dan dapat meningkatkan perekonomian Perempuan Gayo di masa Covid-19, kata Kadis KB, Pemberdayaan Perempuan dan Perlindungan Anak (KBP3A) Kab. Aceh Tengah, bapak Drs Alam Suhada, MM saat memberikan Kata Sambutan Pembukaan Pelatihan Produksi Instan Jahe di Kampung Daling Tajuk Dilem. Taraf hidup masyarakat dapat ditingkatkan melalui berbagai kegiatan yang dapat membantu peningkatan finansial, salah satu kegiatan tersebut adalah bimbingan dan pelatih produksi MJI berbahan baku alami dan tumbuh di sekitar lingkungan tempat tinggal, disenangi masyarakat, dan bermanfaat untuk kesehatan, tambah Ketua Tim PKM Dr. Samran, M.Si., Apt.

MJI punya banyak keunggulan dibandingkan sediaan yang belum diolah atau sediaan cair yang selama ini dijajakan kepada masyarakat (13). Keunggulan MJI, antara lain: masa kadaluarsa lebih lama, tampilan menarik (14), bobot lebih ringan (15), nilai jual lebih tinggi, pemasaran lebih luas, tidak hanya dijajakan door to door, tetapi dapat dipasarkan melalui kios, toko, rumah makan, koperasi unit desa atau swalayan maupun secara online (16).

Pembuatan MJI mudah, murah, peralatan sederhana $(16,17)$, sehingga dapat diproduksi IRT. Oleh karena itu, bimbingan dan latihan pembuatan MJI, cara pengemasan dan pemasaran juga sangat diperlukan IRT. Keterampilan produksi MJI dapat memberi konstribusi peningkatan finansial, dan pada akhirnya meningkatkan taraf hidup keluarga lebih sejahtera. Oleh karena itu, perlu dilakukan Pelatihan Produksi MJI bagi IRT yang tergabung dalam kelompok PKK Kampung Daling Tajuk Dilem, Bebesen, Aceh Tengah, Nanggroe Aceh Darussalam.

\section{METODE}

\section{Survei dan Pendekatan Tim PKM}

Langkah yang dilakukan Tim PKM untuk melaksanakan kegiatan Pelatihan Produksi MJI, yaitu: survay melalui wawancara untuk melihat kondisi masyarakat dan minat maupun antusias Ibu-ibu PKK dalam menaggapi kegiatan PKM. Mengundang Ibu-ibu rumah tangga di bawah kelompok PKK dan anggota keluarga berkumpul di Balai Desa untuk mengikuti bimbingan dan pelatihan. Memberi ceramah keunggulan MJI. Menjelaskan cara pembuatan MJI dengan alat-alat sederhana. Membimbing lansung membuat MJI berbahan baku utama Jahe. Mennyampaikan kalkulasi dana produksi dan harga jual produk. Menjelaskan budidaya Jahe yang baik di pekarangan dan lahan kosong di sekitar tempat tinggal untuk menunjang kegiatan produksi.

\section{Pembuatan Sediaan Minuman Sehat Jamu Instan Kering Bahan dan Alat}

Bahan baku terdiri dari rimpang Jahe merah, gula dan air serta daun pandan. Alat yang digunakan terdiri dari: ember plastik, gunting, kuali, seperangkat kompor, batang pengaduk kayu, pengemas katong plastik.

\section{Proses Penghalusan bahan}

Rimpang Jahe merah dipilih yang cukup tua, disortir (tidak busuk, tidak kisut) dan dipilih yang masih segar. Kemudian kotoran dibersihkan dengan cara dicuci, lalu dirajang dan dihaluskan dengan blander (16-18). 


\section{Proses Pemerasan}

Sebagian rimpang Jahe merah diblender dengan $500 \mathrm{ml}$ air, disaring dan sari ditampung. Sari digunakan untuk blender rimpang Jahe berikutnya sampai kapasitas produksi $2 \mathrm{~kg}$ rimpang Jahe (19). Semua filtrat ditambah serbuk gula sebanyak seperampat bagian dari yang dibutuhkan, selanjutnya diaduk sampai semua gula terlarut sehingga diperoleh campuran sempurna (20).

\section{Proses Perebusan}

Campuran sempurna dimasak dalam kuali bersih dengan api sedang dan dilakukan pengadukan berkesinambungan agar tidak terjadi penggumpalan dan hangus (17). Proses dilakukan sampai adonan kental. Kemudian ditambahkan sisa serbuk gula. Pengadukan tetap dilakukan sampai adonan menjadi kristal. Kristal dihaluskan dengan pengaduk kayu hingga menjadi serbuk (19). Selanjutnya diangkat dan didinginkan (17).

\section{Proses Pengayaan}

Serbuk diayak mesh 12 hingga diperoleh Jahe Instan. Serbuk yang tidak lewat ayakan dihaluskan lagi dengan blander. Serbuk ini disebut MJI beraroma Pandan (17). Akhirnya serbuk dikemas sehingga bisa dipasarkan sebagai minuman siap saji, atau dititip jual di kios, rumah makan, swalayan ataupun secara online (16).

\section{HASIL DAN PEMBAHASAN}

\section{Survei dan Pendekatan Tim PKM}

Kampung Daling Tajuk Dilem berada di wilayah Kec. Bebesen, Kab. Aceh Tengah Provinsi NAD. Gambar 1 menunjukkan Kantor Kampung Daling, Bebesen sebagai Mitra PKM.

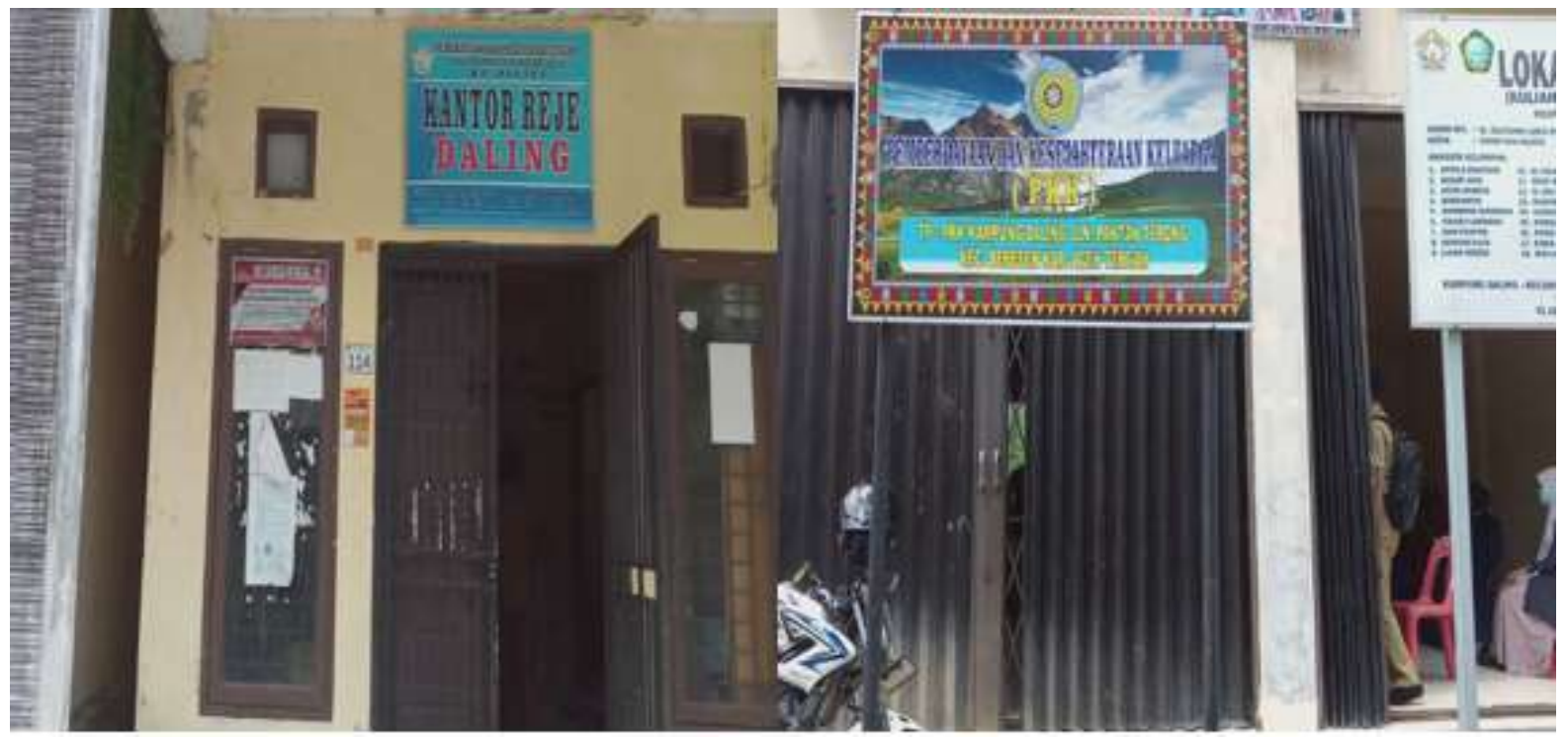

Gambar 1. Kantor Reje Daling Mitra Pengabdian Kepada Masyarakat Program Studi S1 Farmasi STIKes Indah Medan dan Program Studi Farmasi SMK Al Razi Sinar Harapan Medan

Berdasarkan survei melalui wawancara Tim PKM, IRT mempunyai kegiatan terbatas bersama suami sebagai petani kopi. Hasil pantauan Tim PKM, IRT berminat dan antusias diberi bimbingan dan latihan pembuatan MJI dengan harapan dapat meingkatkan perekonomian Perempuan Gayo di masa Covid-19. MJI berbahan baku Jahe merah yang didapatkan di sekitar lingkungan tempat tinggal merupakan salah satu solusinya.

Pelaksanaan kegiatan PKM bagi masyarakat tidak ditemukan hambatan yang berarti, hanya ditemukan hambatan sederhana yang dapat ditanggulangi, yaitu: masyarakat peserta tidak paham dengan istilah instan, keunggulan sediaan instan dibandingkan bentuk cair atau diminum langsung tanpa diolah, sehingga merasa kurang berminat, namun dengan pendekatan yang dilakukan secara intensif serta diberi contoh sediaan jadi, akhirnya antusias pada saat praktek pembuatan. Pengaturan jadwal 
pelatihan agak sulit diatur, karena ada kegiatan lain ibu-ibu selama masa pandemik Covid-19. Kesepakatan tercapai setelah dilakukan komunikasi intensif dan toleransi, kegiatan PKM dapat dijalankan dengan baik.

Tim PKM STIKes Indah Medan, dikoordinasi oleh bapak Dr. apt. Samran, M.Si; Ibu Dra. Apt. Elvy Oktima, bapak apt. Suprianto, S.Si., M.Si; bapak apt. Sumardi, S,Si., MSc., Ibu Dr. Apt Cut Fatimah, M.Si., Ibu apt. Debi Meilani, M.Si. melaksanakan PKM membagi keterampilan kepada Ibuibu PKK Kampung Daling Tajuk Dilem, Bebesen, Aceh Tengah untuk membuiat MJI dengan berbahan baku utama Jahe Merah yang dapat tumbuh di sekitar lingkungan tempat tinggal. Bapak Drs Alam Suhada, MM selaku Kadis KBP3A Aceh Tengah beserta jajarannya mendampingi Tim PKM dengan penuh antusias dan memberi semangat kepada Ibu Tim PKK Kampung Daling, Bebesen, Aceh Tengah. Gambar 2 merupakan dokumentasi Tim PKM, Kadis KBP3A Aceh Tengah dan Ibu PKK Kampung Daling, Bebesen, Aceh Tengah.

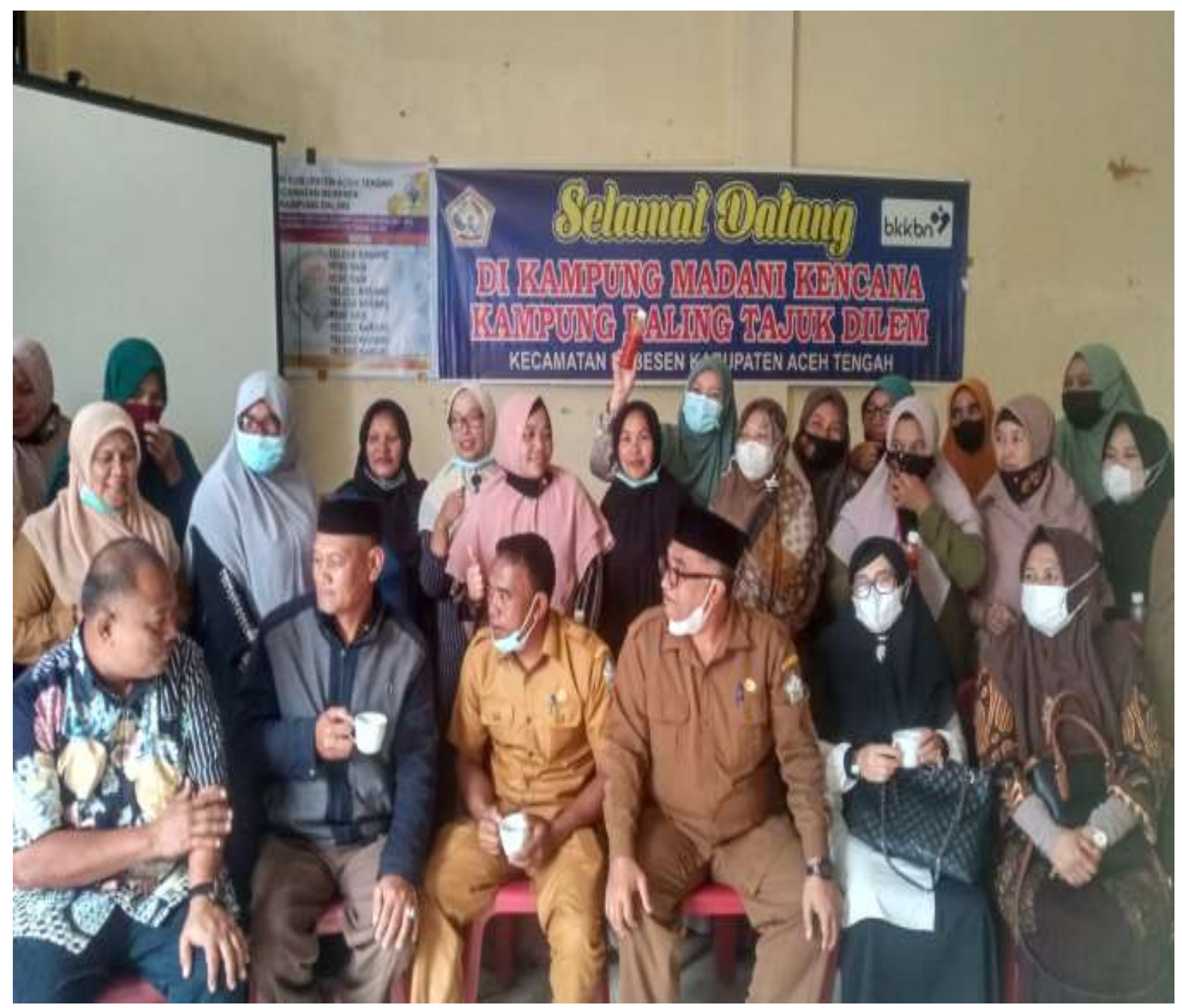

Gambar 2. Tim PKM, Kadis KBP3A Aceh Tengah dan Ibu PKK Kampung Daling, Bebesen, Aceh Tengah, Nanggroe Aceh Darussalam.

\section{Kebutuhan Bahan dan Alat}

Pembuatan sediaan MJI sangat mudah dan dengan biaya murah, peralatan sederhana, dapat diproduksi ibu rumah tangga Kampung Daling, Bebesen, Aceh Tengah. Bimbingan dan pelatihan memberikan penjelasan biaya pembuatan MJI yang menjadi cikal bakal produk rumah tangga dalam kegiatan PKM tersebut. Tabel 1 dan Tabel 2 menunjukkan bahan baku, alat dan biaya produksi MJI.

Tabel 1. Harga Peralatan Produksi MSJIK 
Samran, Suprianto, dkk. Pelatihan Produksi Minuman Jahe Instan Ibu PKK Kampung Daling

\begin{tabular}{lrrr}
\hline Material & Jumlah (buah) & Harga @ (Rp) & Total Harga (Rp) \\
\hline Ember Plastik & 1 & $25.000,-$ & $25.000,-$ \\
Kompor & 1 & $210.000,-$ & $210.000,-$ \\
Tabung & 1 & $105.000,-$ & $105.000,-$ \\
Bahan Bakar & 1 & $25.000,-$ & $25.000,-$ \\
Pengemas Plastik & 132 & $200,-$ & $26.400,-$ \\
Gunting & 1 & $8.000,-$ & $8.000,-$ \\
Pengaduk Kayu & 1 & $13.000,-$ & $13.000,-$ \\
Penyaring & 1 & $20.000,-$ & $20.000,-$ \\
Pisau Potong & 1 & $15.000,-$ & $15.000,-$ \\
\hline \multicolumn{2}{c}{} \\
\hline
\end{tabular}

Tabel 1 menunjukkan bahwa investasi alat untuk pembuatan MJI tidaklah mahal, masih terjangkau oleh Ibu-ibu Kampung Daling, Bebesen, Aceh Tengah. Bahkan sebagian alat sudah tersedia di rumah tangga masing-masing, seperti: seperangkat kompor gas, pisau potong, penyaring, gunting dan ember plastik yang biasa digunakan sehari-hari oleh semua lapisan masyarakat. Ini menunjukkan bahwa Ibuibu Kampung Daling, Bebesen, Aceh Tengah hanya tinggal mempersiapkan pengemas dan isi tabung gas pada proses produksi. Pengemas yang digunakan berupa plastik yang sudah didesain dengan klem sehingga tidak merepotkan Ibu-ibu tersebut.

Tabel 2 merupakan rincian bahan baku yang dibutuhkan sekaligus formula MJI yang bakal diproduksi. Tabel tersebut menunjukkan bahwa untuk invertasi tidaklah terlalu berat, masih terjangkau oleh masyarakat umumnya atau Ibu-ibu Kampung Daling, Bebesen, Aceh Tengah khususnya. Dalam pelatihan juga disampaikan bahwa komposisi campuran yang setara masih dapat diturunkan sehingga biaya bahan baku masih bisa ditanggulangi oleh Ibu-ibu tersebut, misalnya dibagi dua sehingga biaya produksi bisa setengah dari yang tertera pada Tabel 2.

Produksi MJI yang tertera pada Tabel 2 akan menghasilkan serbuk MJI seberat 2200 gram. Bahan bakar yang digunakan dapat memproduksi $12 \mathrm{~kg}$ bahan baku Jahe Merah, sehingga total serbuk Jahe Instan yang dihasilkan 13,2 kg. Kemasan yang disiapkan memuat serbuk seberat $100 \mathrm{~g}$ dengan harga jual Rp 10.000,- sehingga total kemasan sebanyak 132 kemasan dengan hasil jual sebesar Rp 1320.000,. Ini menujukkan bahwa Ibu-ibu sudah dapat tambahan finansial sebesar Rp 487400,- sekali produksi, karena biaya rutin yang harus dikeluarkan 6 x Rp 80200,-- plus Rp 26400,- ; Rp 300.000,- dan Rp 25000 yang masing-masing dari item bahan baku, pengemas dan tenaga kerja serta bahan bakar.

Tabel 2. Bahan Baku dan Biaya Produksi MSJIK

\begin{tabular}{lcrr}
\hline Nama Bahan Baku & Jumlah $(\mathbf{k g})$ & Harga @ (Rp) & Total Harga \\
\hline Jahe Merah & 2 & $25.000,-$ & $50.000,-$ \\
Gula & 2 & $15.000,-$ & $30.000,-$ \\
Daun Pandan & 2 & $200,-$ & $200,-$ \\
\hline \multicolumn{4}{c}{ Total Biaya (Rp) } \\
\hline
\end{tabular}

\section{Pelatihan Produksi}

Gambar 3 dan Gambar 4 menunjukkan suasana pelatihan produksi MJI. Pelatihan produksi dimulai dari tahap awal sampai menjadi produk MJI dan mengemas produknya. Tampak bahwa dalam pelatihan suasana keakraban dan keikhlasan dalam membimbing Ibu PKK Kampung Daling Tajuk Dilem, Bebesen, Aceh Tengah. 
MEJUAJUA: Jurnal Pengabdian Kepada Masyarakat Vol 1 No 2, Desember 2021

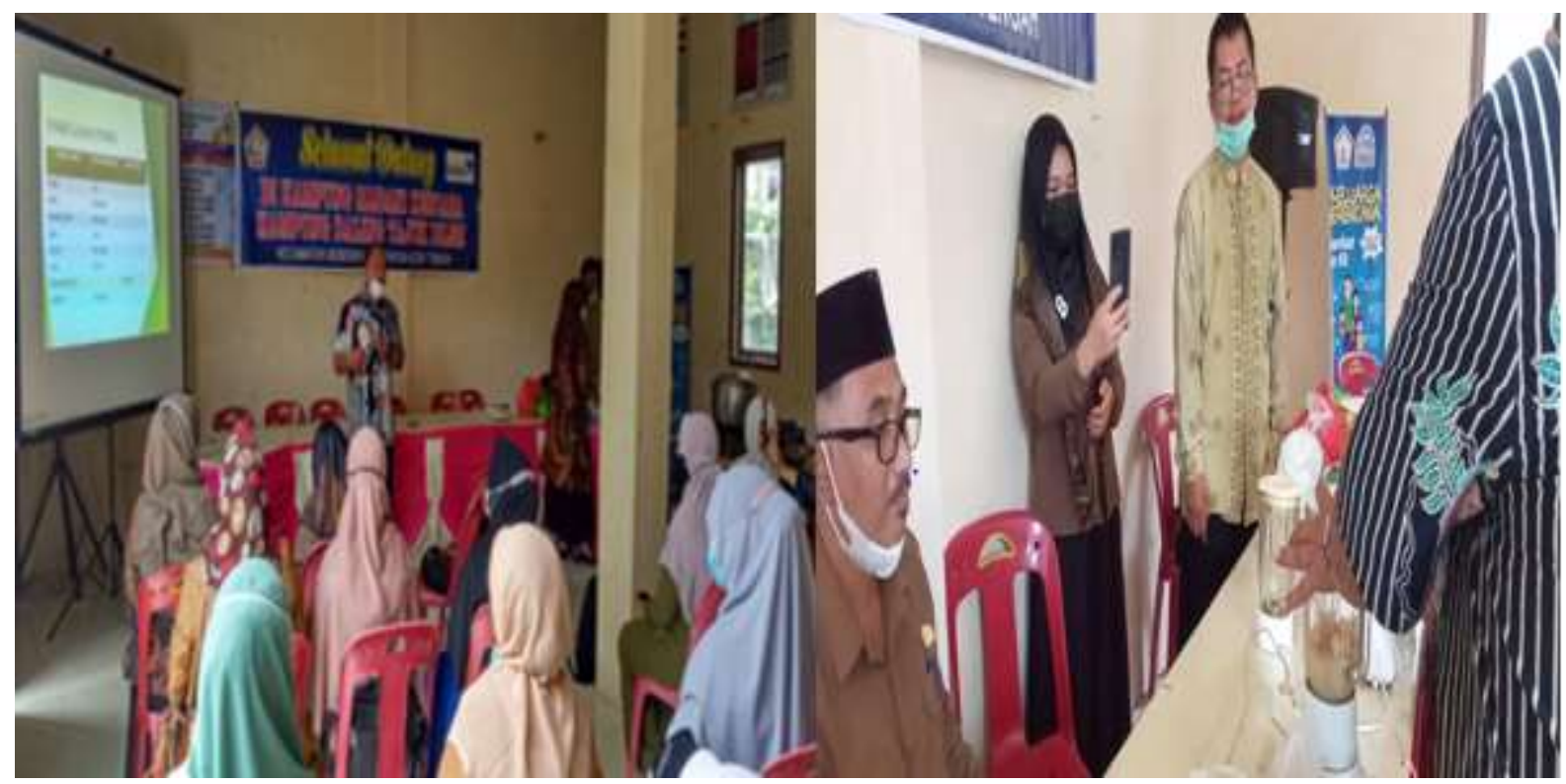

Gambar 3. Tim PKM Memberikan Pelatihan Produksi MJI pada Ibu PKK Kampung Daling, Bebesen, Aceh Tengah dengan Didampingi Kadis KBP3A Aceh Tengah, Bapak Drs. Alam Suhada, MM.

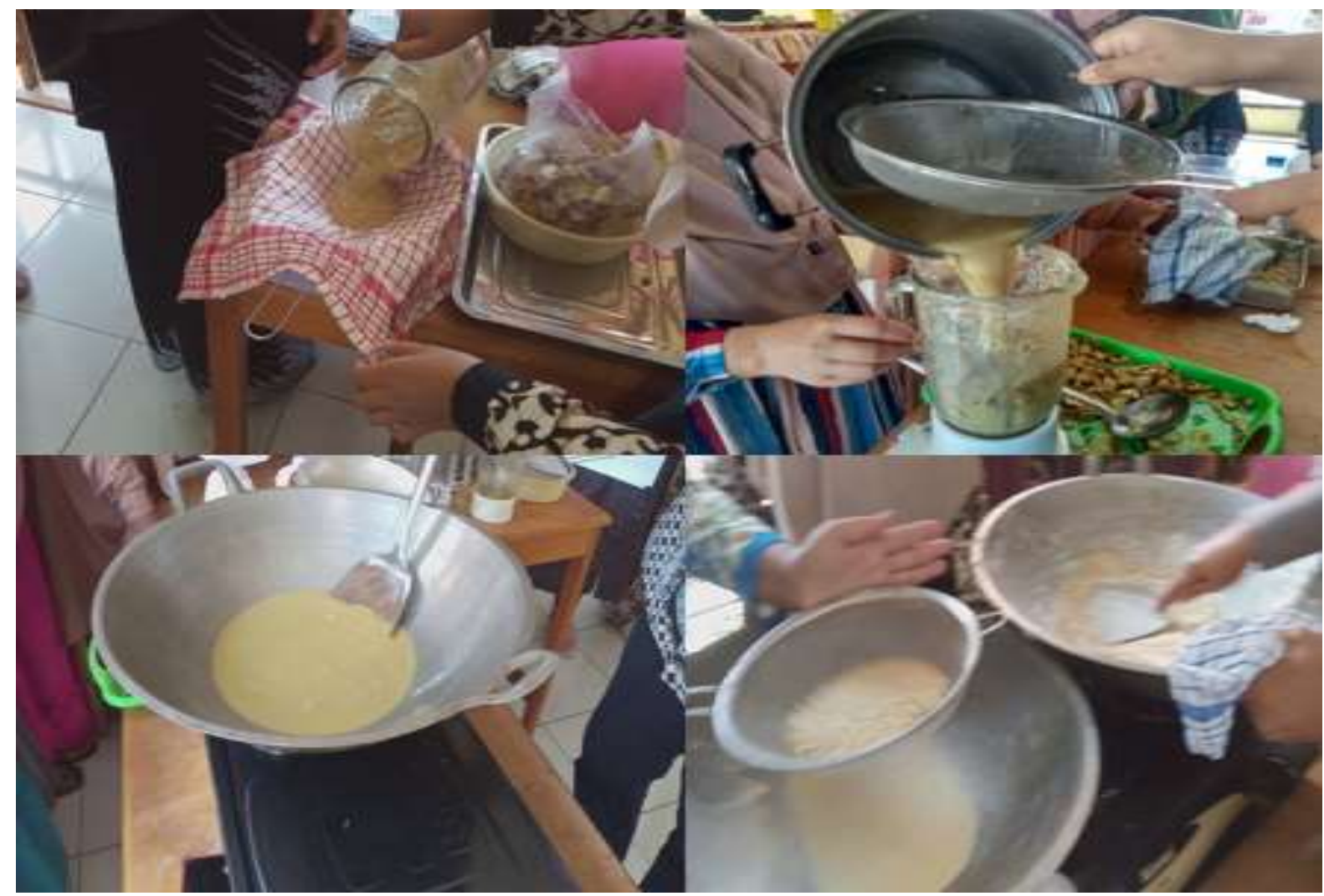

Gambar 4. Ibu PKK Kampung Daling, Bebesen, Aceh Tengah Ikuti Pelatihan Produksi MJI

\section{KESIMPULAN}

Kegiatan PKM telah selesai dilaksanakan dengan hasil sangat dirasakan oleh Ibu-ibu PKK Kampung Daling, Bebesen, Aceh Tengah, karena telah mempunyai ketrampilan dalam pembuatan sediaan MJI menggunakan bahan baku utama Jahe Merah dan besar harapan dapat meningkatkan perekonomian Perempuan Gayo dimasa Covid-19. 


\section{DAFTAR RUJUKAN}

1. Wiradnyana K, Setiawan T. Merangkai Identitas Gayo. Jakarta: Yayasan Pustaka Obor Indonesia; 2011.

2. Sutrisno S, Harnedi J. Membangun Masyarakat Sadar Wisata dan Sadar Bencana di Kawasan Danau Lut Tawar Takengon. J As-Salam. 2018;2(3):93-102.

3. Arinalun TA, Wahyono H. Kajian Daya Tarik Kawasan Danau Lut Tawar sebagai Tujuan Wisata di Kabupaten Aceh Tengan. Universitas Diponegoro; 2018.

4. Khaironi K, Soesilowati E, Arsal T. Kearifan Lokal Masyarakat Etnis Gayo Sebagai Destinasi Wisata Budaya di Kota Takengon. J Educ Soc Stud. 2017;6(2):99-110.

5. Hulupi R, Nugroho D, Yusianto. Keragaan Beberapa Varietas Lokal Kopi Arabika di Dataran Tinggi Gayo. Pelita Perkeb. 2013;29(2):69-81.

6. Ellyanti E, Karim A, Basri H. Analisis Indikasi Geografis Kopi Arabika Gayo Ditinjau dari Rencana Tata Ruang Wilayah Kabupaten. J Agrista. 2012;16(2):46-61.

7. Isma YS. Strategi Dinas Pariwisata Pemuda dan Olahraga dalam Mengembangkan Daerah Tujuan Wisata Danau Laut Tawar di Kabupaten Aceh Tengah. Universitas Sumatera Utara; 2017.

8. Tillah RM. Aceh Tengah Racecourse. J Ilm Mhs Arsit dan Perenc. 2019;3(4):43-7.

9. Sari DP, Kamal S, Hanim N. Komposisi Jenis Plankton di Danau Lut Tawar Kabupaten Aceh Tengah. Pros Biot. 2019;6(1).

10. Adhar S, Barus TA, Nababan ESM, Wahyuningsih H, Erlangga E, Khalil M. Estimasi Potensi Produksi Ikan Di Danau Laut Tawar Berdasarkan Morphoedaphic Index. J Serambi Eng. 2020;5(3). 